\title{
STABILITY AND SATISFACTION AT WORK DURING THE SPANISH ECONOMIC CRISIS
}

\section{María Carmen Sánchez-Sellero, Pedro Sánchez-Sellero, María Montserrat Cruz-González, Francisco Javier Sánchez-Sellero*}

\begin{abstract}
This paper analyses temporary work and job satisfaction among salaried workers during the Spanish economic crisis of 2008. Using data from the Spanish National Statistics Institute (INE) 2013 Economically Active Population Survey (EAPS), we find that temporary workers lost their job more than others during this period. However, salaried workers have higher average levels of satisfaction in 2007-2010, possibly due to the lower requirements of workers. We find a positive relationship between the unlikeliness of keeping a job and low job satisfaction levels in data from the Survey of Quality of Life at Work (2010) through a correspondence analysis. A linear model with a level of job satisfaction as a dependent variable shows negative coefficients for a level of job satisfaction if the probability of keeping the job is somewhat unlikely or very unlikely. Finally, an ordinal probit regression finds that the estimated likelihood to reach high job satisfaction is lower in temporary workers.
\end{abstract}

Keywords: stability, temporary work, satisfaction, crisis, employability

JEL Classification: C12, J24, J28

\section{Introduction}

In 2007, the percentage of temporary workers in Spain was twice as high as in the rest of Europe. Contracts were the main way to provide flexibility for companies during the economic crisis, (Instituto Valenciano de Investigaciones Económicas, IVIE 2012a- Valencian Institute of Economic Research). So, the greater impact of the economic crisis that began in 2008 affects the Spanish labour market. A study of the European labour market in this economic crisis can be seen for example in Dimian et al. (2013). Today, the numbers temporary workers and the proportion of unemployed workers $(21.18 \%$ in the third quarter of 2015 according to the 2015 Economically Active Population Survey from the Instituto Nacional de Estadística INE- Spanish National Institute of Statistics) are very high in Spain. In this paper, we analyse whether these temporary contracts, an indicator of job instability, affect the level of job satisfaction in Spain. For this purpose, we conduct static and dynamic studies.

* María Carmen Sánchez-Sellero, University of Coruña, Department of Applied Economics II, Faculty of Economics and Business Administration, La Coruña, Spain (c.sanchez@udc.es); Pedro Sánchez-Sellero, University of Zaragoza, Department of Business Administration, School of Engineering, Zaragoza, Spain (pedross@unizar.es);

María Montserrat Cruz-González, University of Vigo, Department of Business Administration, Faculty of Economics and Business Administration, Vigo- Pontevedra, Spain (mcruz@uvigo.es); Francisco Javier Sánchez-Sellero, University of Vigo, Department of Business Administration, Faculty of Economics and Business Administration, Vigo- Pontevedra, Spain (javiss@uvigo.es). The authors acknowledge the funding received from MINECO-FEDER (Project ECO201236290-C03-01) and DGA-FSE (Project S125: Compete Research Group). 
Using data from the 2013 Economically Active Population Survey, we focus on the effect of the Spanish economic crisis on salaried workers with permanent and temporary contracts through 2012. Using data from the Ministry of Employment and Social Security, we also analyse the changes in job satisfaction for each type of employment contract during 20062010. We then evaluate this data to determine if job satisfaction is related to job retention. First, we calculate measures of association and correspondence analysis; then we explain the level of job satisfaction through a linear model and an ordinal probit regression. Both models use different variables and methodologies. In the empirical analysis, we use data from the Ministry of Employment and Social Security's 2010 Survey of Quality of Life at Work (published in December 2014).

The goal of this paper is threefold: 1) to study how the economic crisis affects the number of workers with permanent and temporary contracts, 2) to understand how the type of job contract affects job satisfaction for salaried workers during the economic crisis, and 3) to explain the level of job satisfaction in each year of the economic crisis through the application of different methodologies (correspondence analysis, linear modelling, ordinal probit regression).

The structure of this paper is as follows. Sections 2,3, and 4 provide a theoretical framework of stability and employability, as well as describe employees by type of contract and level of job satisfaction during the Spanish economic crisis. Section 5 presents the database that we use. Section 6 develops the methodology. Section 7 contains results and a discussion of empirical analysis, and Section 8 concludes.

\section{Stability and Employability}

The majority of the authors explain job stability in the following way. Job stability is the right of the workers to keep their job if they do not fall into any of the grounds for dismissal established by law; and the employer have to keep workers in their job if they do not fall into any of the grounds for dismissal. However, the word employability comes from the joining together of the words "employment" and "ability". So, worker employability is the knowledge and skills that increase the workers capacity to get and keep a job, improve their work and adapt to change. In fact, the worker employability is the likely to have and keep a job according to the worker skills.

Socorro (2004) finds that ensuring job stability for employees is one of the most important topics to lawyers, trade unionists, and politicians. This is important because it is easy to assume that job stability depends only on ensuring that employers only conduct layoffs in justified circumstances or on ensuring long-term employment. But to what extent do employees have responsibility for job stability?

In some cases, when employees feel secure in the workplace, they no longer strive to improve their performance or become more productive. Instead, some employees limit themselves to their areas of competence. This behaviour is unattractive and profit-draining, yet these employees often show entrepreneurial and innovative behaviour at the beginning of the employment relationship. Why then should a company ensure the job stability of an employee who no longer adds value?

Permanent-employee status and tenure provide a sense of perpetuity to an employee's relationship with a company; this manifests itself in recognition for years of service, which is how employees demonstrate loyalty and commitment to the organization. Thus, longevity of an employer-employee relationship can identify good workers. However, this concept is 
questionable. As Socorro (2004) finds, experience with a company has value, even if unpaid.

However, the concept of job stability cited previously rises from the notion that layoffs are an exclusive power of the company and that employees leave voluntarily to express dissatisfaction. We believe that in an economic crisis, this notion is inapplicable because of the scarcity of jobs. Additionally, when a worker is fired or quits, he immediately loses a place in the labour market and may not be attractive to employers. In turn, this affects the employee's job stability.

Employees get job stability if they are innovative and if they add value to organizations, independently of their social status, age, or other considerations (Socorro, 2004). Job stability is thus a shared responsibility that ensures effective participation and added value to processes, products, or services. Employees do achieve stability if there is an employer who creates jobs, however. For this reason, if economic conditions deteriorate, workers may lose their jobs and may have little expectation of recovering them unless their employment status helps them get new jobs easily.

One of the main factors that affect job performance is remuneration. This can occur through negotiation and approval of collective-bargaining contracts that comply with current laws and dictate living wages that satisfy workers and improve their performance (Pedraza et al., 2010). Gamero (2005) also states that job stability and promotion opportunities have a strong impact on job satisfaction. Bowling et al. (2005) present several alternative theories of stability and explain how the environmental effects on job satisfaction dissipate over time.

Companies cannot guarantee long-term employment, however, but they can ensure that their workers are employable by giving them experience and training that will increase their value in the labour market (Jacoby, 1999). Cesário et al. (2012) show the cases that the employability can have a moderating effect on the relationship between the type of contract, affective commitment and job satisfaction. Employability is the ability to find a job easily. The basic idea is that workers cannot expect companies to ensure job stability; instead, workers should focus on guaranteeing their future employability (Álvarez and Miles, 2006). A worker's employability improves if he or she becomes more valuable in the labour market. Employability is thus a nontraditional form of job security (Finn, 2000; Truch, 2001; Stone, 2001; Scholarios et al, 2008; De Cuyper et al., 2011).

If a firm favours improving the employability of its workers, it improves their job satisfaction (Álvarez and Miles, 2006). We know that perceived job security and job status (permanent or temporary) affect job satisfaction, and that workers often prefer a temporary but secure job to a permanent but insecure one (Origo and Pagani, 2009). Accordingly, the job's contract duration could be less important to workers if workers perceive that their jobs are not at risk (Origo and Pagani, 2009).

Authors have different stances in relation to satisfaction. For these authors (Cesário et al., 2012), the greater job insecurity does not imply less job satisfaction and less job commitment. In this line, the results of Bernhard-Oettel et al. (2005), De Witte and Naswall (2003) and Guest and Conway (1997) do not support the hypothesis that temporary workers are less satisfied with their job than permanent workers, and their findings cannot establish a clear relationship between type of employment contract and job satisfaction.

In Elfering et al. (2000), changes in mean levels of job satisfaction and work centrality are higher for employees who change jobs than for those who do not. Agypt and Rubin 
(2012) analyse how the temporal constraint of the organization and changes in temporary structures in the workplace affect satisfaction. Similarly, Dormann and Zapf (2001) show how job satisfaction affects job change. Wilkin (2013) numerically summarizes potential mean differences in job satisfaction between temporary and permanent workers. Those results suggest that in general, temporary workers have the lowest job satisfaction compared to permanent employees.

Therefore, temporary workers should value improvements in employability more because those improvements compensate for the negative effects that a temporary contract has on job satisfaction.

\section{Temporary Work In Spain: Theoretical Review}

The Spanish labour market is now a dual market after the introduction of temporary job contracts (Alba, 1998; Amuedo, 2000). Galtier and Gautié (2001) propose the "Employment Queue", which says that workers who want to enter the labour market must first queue in the unemployment line or take temporary employment while they wait for a stable job. These workers are called "temporary outsiders".

During the years before the Spanish economic crisis (2006 and 2007), the unemployment rate decreased substantially and was below $10 \%$ for the first time in decades. In this context of job creation and expanding stable employment, the transition from temporary to stable employment improved. Economists considered Spanish regions with the most dynamic labour markets as fully employed, at least for men. A few years later, the labour market completely changed due to the Spanish economic crisis. Now, several million workers are unemployed.

There is also a direct relationship between education level and type of contract (IVIE, 2009a). The more educated the worker, the higher the probability of having a permanent contract. Age and gender also influence the probability of having a permanent contract. The proportion of older workers rises in permanent jobs; autonomous, geographically mobile jobs; and highly skilled jobs. The proportion of younger workers rises in temporary jobs, jobs with flexible hours, part-time jobs, and low-skill jobs (IVIE, 2009b).

There are four groups of young people in relation to employment flexibility (IVIE, 2009b). The first are those with permanent jobs or self-employment, generally associated with adequate qualifications and full-time jobs. The other three groups involve temporary contracts. Two are classified according to dedication (one full-time, the other part-time), and the third is classified by the versatility of tasks in the workplace. There are more women in the temporary jobs and more men in the permanent jobs. Young people who continue their studies are more likely to hold part-time, temporary jobs or functional-flexibility jobs. Young people who finish their studies usually get permanent jobs, self-employment, or full-time temporary jobs. Before the Spanish economic crisis in 2008, employment rates and the proportion of temporary job contracts were higher. This trend is now more evident in women. Young people also find it difficult to access the labour market, especially during an economic crisis. They also tend to be unemployed longer and overqualified for the jobs they do obtain.

The economic crisis of 2008 stimulates new ways of employment relations marked by a higher unemployment and job instability (Laparra et al., 2012). The higher precarious jobs seem to be as a key factor of exclusion. So, the employment gradually loses its integrative capacity. 
The greater use of temporary workers facilitates the firm adaptation to the economic cycle. As a consequence, many workers lose their job and seek for a new job. An analysis of the professional careers of some groups shows that the temporary contract is the gateway to the labour market. However, the economic crisis has contributed to the temporary job destruction, the more slowly transition to permanent contracts, the higher unemployment and the very slightly higher labour inactivity (Fundación FOESSA, 2014). Medina et al. (2010) propose this idea in similar terms.

The Spanish economy is cyclical (Merino et al., 2012). In turn, the creation and destruction of jobs is correlated with the economic cycle (Merino et al., 2012). During the economic crisis, job destruction was high, which carried a high social cost (Merino et al., 2012). It also increased the amount of temporary and short-duration contracts ${ }^{1}$, though an increase in better-quality ${ }^{2}$ jobs does not accompany an increase in education level. Strategies to restore the Spanish economy and make it more competitive therefore include reducing the number of temporary job contracts, promoting the creation of more and better jobs, and adding more quality jobs (International Labour Organization, 2011).

Regarding Spanish employment legislation for the regulation of temporary contracts, Muñoz (2015) states that one of the most important and problematic issues in all the employment reforms has been the temporary nature of contracts. We must refer to article 15 of the Spanish Workers' Statute, which establishes the length of the various kinds of temporary employment in Spain. It distinguishes between:

1. Contracts for work or service: This type of contract will have a maximum length of 3 years (extendable by 12 months if the applicable collective bargaining agreement so establishes).

2. Temporary contracts due to market conditions, an accumulation of tasks or an excess of orders. These will have a maximum length of 6 months within a period of 12 months (although this can also be extended up to 12 months in a period of 18).

3. Substitution contract. The purpose of these contracts is to substitute someone who has the right to reserve their job. These will not have a maximum length, as they will last until the substituted person returns to work.

However, the problem arises when we have to apply article 15.5 of the Workers' Statute, because it establishes that those workers who during a period of 30 months have been employed for a period of over 24 months, continuously or not, in the same or different job with the same company or group of companies, through two or more temporary contracts, whether directly or through employment agencies, with the same or different fixed-term contract types, will become permanent workers.

There are two exceptions in calculating the temporary employment time: 1) substitution contracts are not included in this temporary calculation, 2) the evolution of this precept due

1 The frequent use of these contracts causes a high labour rotation. Also, they affect negatively human capital and labour productivity in the analysed period (Toharia, 2005).

2 In the words of Fernández (2013), the International Labour Organization (ILO) gave a definition of quality job that guided countries to achieve better labour conditions more than a decade ago. It is a job in which labour rights are protected, productive, fairly paid, implemented freely with equity, freely, equity, security and able to guarantee a dignified life. The existence of quality job is based on four pillars: protection of labour rights, promotion of quality jobs, growth of social protection and social dialogue. 
to all the employment reforms has meant that the period between $31^{\text {st }}$ August 2011 and $31^{\text {st }}$ December 2012 are not included in the calculation of the 24 months.

\section{Temporary Job Contracts and Job Satisfaction in Spanish Economic Crisis of 2008 - Dynamic Study}

It is important to know the types of contracts for salaried workers in Spain (IVIE, 2006). INE data show that the percentage of employees with temporary contracts is always more than 30\% during 1996-2005, since 2003 the trend increases. The percentage of salaried workers with temporary contracts was $23.62 \%$ in 2012 ; it was $31.66 \%$ in 2007 (the year before the beginning of the economic crisis) (INE, 2013). Table 1 shows the immediate consequence of the economic crisis; temporary workers are the most affected.

The number of employees declines every year in absolute value in recent years, as we can see in data from the EAPS Economically Active Population Survey (INE, 2013) (Table 1). We also see that the worst years are 2009 and 2012; in these years the percentage of temporary salaried workers decreases from the previous year by $18.40 \%$ and $12.06 \%$, respectively. During 2007-2012 the total number of salaried workers falls by $15.03 \%$, the number of salaried workers with permanent contracts falls by $5.03 \%$, and the number of salaried workers with temporary contracts falls by $36.6 \%$. Clearly, the reduction is higher in temporary salaried workers. Therefore, when unemployment rates are so high, the first out usually are temporary workers. These figures confirm the study by Medina et al. (2010), which states that the economic downturn produces greater job losses amongst those groups that have a lower level of protection, temporary workers being one of these groups, whose dismissals are cheaper for companies in terms of compensation. Having a temporary contract has a strong impact on the likelihood of workers losing their jobs.

Table 1 | Salaried Workers by Contract Type or Labour Relation, 2006-2012. Interannual Variation Rates. Units: Millions of People

\begin{tabular}{|l|c|c|c|c|c|c|c|}
\hline YEARS & $\mathbf{2 0 0 6}$ & $\mathbf{2 0 0 7}$ & $\mathbf{2 0 0 8}$ & $\mathbf{2 0 0 9}$ & $\mathbf{2 0 1 0}$ & $\mathbf{2 0 1 1}$ & $\mathbf{2 0 1 2}$ \\
\hline Total & $16,208.1$ & $16,760.0$ & $16,681.2$ & $15,680.7$ & $15,346.8$ & $15,105.5$ & $14,241.8$ \\
\hline $\begin{array}{l}\text { Permanent job } \\
\text { contracts }\end{array}$ & $10,691.4$ & $11,453.1$ & $11,800.7$ & $11,698.3$ & $11,523.6$ & $11,279.5$ & $10,877.2$ \\
\hline $\begin{array}{l}\text { Temporary job } \\
\text { contracts }\end{array}$ & $5,516.7$ & $5,306.9$ & $4,880.5$ & $3,982.4$ & $3,823.2$ & $3,825.9$ & $3,364.6$ \\
\hline $\begin{array}{l}\text { Total interannual } \\
\text { variation rate }\end{array}$ & - & $3.40 \%$ & $-0.47 \%$ & $-6.00 \%$ & $-2.13 \%$ & $-1.57 \%$ & $-5.72 \%$ \\
\hline $\begin{array}{l}\text { Interannual variation } \\
\text { rate of permanent job } \\
\text { contracts }\end{array}$ & - & $7.12 \%$ & $3.03 \%$ & $-0.87 \%$ & $-1.49 \%$ & $-2.12 \%$ & $-3.57 \%$ \\
\hline $\begin{array}{l}\text { Interannual variation } \\
\text { rate of temporary job } \\
\text { contracts }\end{array}$ & - & $-3.80 \%$ & $-8.03 \%$ & $-18.40 \%$ & $-4.00 \%$ & $0.07 \%$ & $-12.06 \%$ \\
\hline
\end{tabular}

Source: Own elaboration from the Economically Active Population Survey, EAPS (INE, 2013). 
This temporary job contracts affect the labour market and job satisfaction; in turn, they affect workers' behaviour. So, we study the level of job satisfaction during the Spanish economic crisis. Table 2 reflects average job satisfaction for salaried workers by type of contract (permanent or temporary) during the two years before the beginning of the Spanish economic crisis and to 2010 (the latest available). The data is from the Survey of Quality of Life at Work.

We find that women have higher job satisfaction than men, and that temporary workers have lower job satisfaction than permanent workers. We also find that the average level of job satisfaction increases at a slower rate during the Spanish economic crisis than in 2007. In 2007, for instance, the increase in the average level of job satisfaction in permanent salaried workers is $2.74 \%$ and the increase in the average level of satisfaction in temporary salaried workers is $2.94 \%$. This may be due to the high unemployment rate, which means that employed workers are more likely to report higher job satisfaction because they feel lucky to have jobs. This idea is consistent with findings from a study of young people (IVIE, 2012b), which shows a decrease in requests for work reassignments, geographical mobility, challenging tasks, etc. since the beginning of the Spanish economic crisis.

Table 2 | Average Level of Job Satisfaction for Salaried Occupied Workers

\begin{tabular}{|l|l|c|c|c|}
\hline \multicolumn{2}{|c|}{} & Total & Men & Women \\
\hline \multirow{3}{*}{ Type of contract for salaried workers in 2006} & Permanent & 7.4 & 7.4 & 7.4 \\
\cline { 2 - 5 } & Temporary/casual & 7.0 & 7.0 & 7.1 \\
\hline \multirow{2}{*}{ Type of contract for salaried workers in 2007 } & Permanent & 7.3 & 7.3 & 7.3 \\
\cline { 2 - 5 } & Temporary/casual & 6.8 & 6.7 & 7.0 \\
\hline \multirow{3}{*}{ Type of contract for salaried workers in 2008 } & Permanent & 7.3 & 7.3 & 7.4 \\
\cline { 2 - 5 } & Temporary/casual & 6.9 & 6.8 & 6.9 \\
\hline \multirow{2}{*}{ Type of contract for salaried workers in 2009} & Permanent & 7.4 & 7.3 & 7.5 \\
\cline { 2 - 5 } & Temporary/casual & 7.2 & 7.1 & 7.3 \\
\hline \multirow{2}{*}{ Type of contract for salaried workers in 2010} & Permanent & 7.5 & 7.5 & 7.5 \\
\cline { 2 - 5 } & Temporary/casual & 7.0 & 6.9 & 7.2 \\
\hline
\end{tabular}

Note: Average level of job satisfaction min. is 0 and max. is 10 .

Source: Own elaboration from the Survey of Quality of Life at Work (Ministry of Employment and Social Security: 2006-2010).

\section{Data}

We use 2010 microdata from the Ministerio de Empleo y Seguridad Social, Encuesta de calidad de vida en el trabajo (ECVT) - Ministry of Employment and Social Security's Survey of Quality of Life at Work. The survey covers the entire Spanish territory except for Ceuta and Melilla, and the population includes employed workers over 16 years old who reside in family households. This database was also used in the paper of job satisfaction by Sánchez-Sellero et al. (2014). 
The ECVT questionnaire has different sections depending on the research objectives, including sociodemographic data (age, gender, and education level), employment situation (variables that describe jobs), and quality of life at work (job satisfaction, job organization, labour environment, labour relations, working time, job safety, academic training, professional training, compensation, attitudes, opinions, collective bargaining, trade unionism, labour mobility, geographical mobility, and work-life balance).

The ECVT sample uses a three-stage stratified sampling. This survey considers in each sampling stratum the crossing of Spanish regions and different levels of municipality size. In the first stage, the survey defines a sample of census sections with probabilities in proportion to the size of each section; in the second stage, it selects from each firststage census section a sample of households (with equal probability for each house in the section); finally, within each second-stage house it randomly selects an employed resident.

\section{Analysis and Explanatory Models - Static Study}

The ECVT survey includes 8,061 people; selecting only employees and self-employed people leaves 6,512 people. Although the sample includes 6,512 people, when we balance it with the elevation factor, it represents a population of $14,979,153$ people. The purpose of our study and the different variables involved justifies the use of different methodologies. In our study, the dependent variable is current job satisfaction level, which takes values from 0 to 10 ( 0 means no satisfaction, and 10 signifies high satisfaction). In order to assess workers' job stability, we use the variable likely to keep job in six months. This variable contains five categories: highly likely, quite likely, somewhat unlikely, very unlikely, and not applicable. We want to see if both variables are independent. We thus propose two hypotheses:

H0: An independent relationship exists between current job satisfaction level and likelihood to keep job in six months.

H1: An independent relationship between current job satisfaction level and likelihood to keep job in six months does not exist.

After performing chi-square tests, we obtain a statistical Pearson chi-squared with a value of $57.951(\mathrm{p}=0.000)$ and a likelihood ratio of $54.104(\mathrm{p}=0.000)$. These values reject the null hypothesis; therefore, both variables are not independent. Thus, we calculate appropriate association measures in the case of contingency tables when categorical variables are nominal (Phi, Cramer's V, and contingency coefficient). In this case, they indicate little association, because the coefficients are next to zero (0.094).

In the following correspondence analysis ${ }^{3}$, we again see that the variables are not independent (see $p=0.000$ in Table 3 ). The total inertia represents the total explanation of the axes (a total of 0.064 explained). Although the inertia may seem small, the four axes explain $100 \%$ of the variance. The first dimension contributes $79.6 \%$ of that inertia, and the first two contribute $92.4 \%$. Because of this, the first two dimensions properly collect the observed dependencies in the contingency table.

3 The correspondence analysis was used in other papers of job satisfaction such as Sánchez-Sellero et al. (2013). 


\begin{tabular}{|c|c|c|c|c|c|c|c|c|}
\hline \multirow{3}{*}{$\begin{array}{l}\text { Dimen- } \\
\text { sion }\end{array}$} & \multirow{3}{*}{$\begin{array}{l}\text { Own } \\
\text { value }\end{array}$} & \multirow{3}{*}{ Inertia } & \multirow{3}{*}{$\begin{array}{l}\text { Chi- } \\
\text { square }\end{array}$} & \multirow{3}{*}{ Sig. } & \multicolumn{2}{|c|}{ Inertia Proportion } & \multicolumn{2}{|c|}{$\begin{array}{c}\text { Confidence } \\
\text { of the Own Value }\end{array}$} \\
\hline & & & & & \multirow{2}{*}{ Explained } & \multirow{2}{*}{ Accumulated } & \multirow{2}{*}{$\begin{array}{l}\text { Std. } \\
\text { Dev. }\end{array}$} & Corr. \\
\hline & & & & & & & & 2 \\
\hline 1 & 0.226 & 0.051 & - & - & 0.796 & 0.796 & 0.015 & 0.299 \\
\hline 2 & 0.091 & 0.008 & - & - & 0.128 & 0.924 & 0.017 & - \\
\hline 3 & 0.065 & 0.004 & - & - & 0.067 & 0.991 & - & - \\
\hline 4 & 0.024 & 0.001 & - & - & 0.009 & 1.000 & - & - \\
\hline Total & - & 0.064 & 416.652 & $0.00^{\mathrm{a}}$ & 1.000 & 1.000 & - & - \\
\hline
\end{tabular}

Note: a - 40 degrees of freedom.

Source: Own elaboration from the Survey of Quality of Life at Work (Ministry of Employment and Social Security, 2010).

Figure 1 shows the relationship between the modes of current job satisfaction level and likelihood to keep job in six months. We apply a symmetrical normalization method whereby for each dimension, the row scores are the weighted averages of the column scores divided by the common eigenvalue, and vice versa (the column scores are the weighted averages of the row scores divided by the coincident eigenvalue). This method is valid to examine differences or similarities between categories of the two variables. If keeping the job is very unlikely, for example, the associated categories are $0,1,2$, and 3 .

Figure 1 | Graphical Representation of the Point Row and Column, Symmetric Normalization

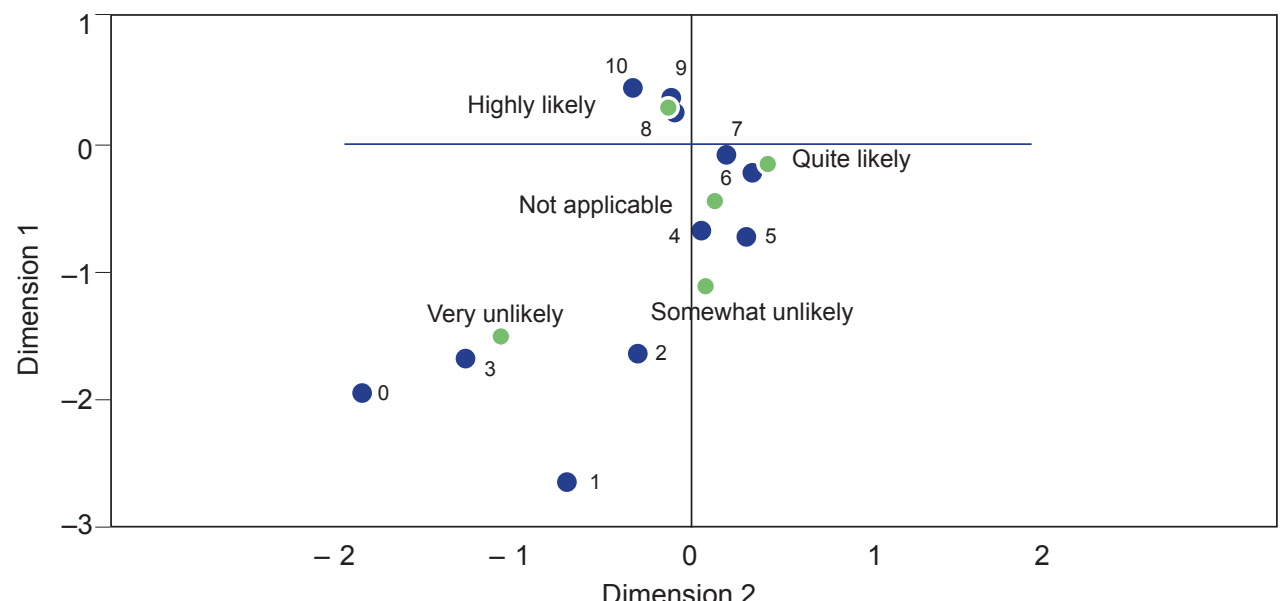

Current job satisfaction level (2010) Likely to keep job in six months

Source: Own elaboration from the Survey of Quality of Life at Work (Ministry of Employment and Social Security, 2010). 
Both models (linear modelling and ordinal probit regression) use current job satisfaction level as the explained variable. The first model uses likelihood to keep job in six months as the explanatory variable. Table 4 shows the mean and standard deviation of current job satisfaction level corresponding to the different categories of likelihood to keep job in six months. The lowest job satisfaction average corresponds to the categories "somewhat unlikely" or "very unlikely".

Table 4 | Descriptive Statistics

\begin{tabular}{|l|c|c|c|}
\hline Likely to keep job in six months & Mean & $\begin{array}{c}\text { Standard } \\
\text { Deviation }\end{array}$ & Number \\
\hline Highly likely & 7.6510 & 1.61176 & 4,163 \\
\hline Quite likely & 7.2132 & 1.71886 & 1,435 \\
\hline Somewhat unlikely & 6.5472 & 2.11745 & 477 \\
\hline Very unlikely & 6.2593 & 2.46064 & 189 \\
\hline Not applicable (contract finalization, retirement, etc.) & 7.0565 & 1.88668 & 248 \\
\hline Total & 7.4106 & 1.75849 & 6,512 \\
\hline
\end{tabular}

Note: Dependent variable: Current job satisfaction level (2010).

Source: Own elaboration from the Survey of Quality of Life at Work (Ministry of Employment and Social Security, 2010).

Table 5 shows that the model is good although the $R^{2}$ is low. There is only one explanatory variable and, logically, many more factors influence the dependent variable explanation. Table 6 shows that if an employee is "somewhat unlikely" or "very unlikely" to keep a job, the coefficients are negative. In these cases, job satisfaction decreases. Except for one, every coefficient is significant (see Table 6). There are redundant parameters in both Table 6 and Table 7 . In both cases, there are as many $\beta_{i}$ parameters as categories, but one is redundant, that is, only 4 parameters are required for 5 categories (Table 6).

Table 5 | Abstract of Linear Model

\begin{tabular}{|l|r|r|r|r|r|}
\hline \multicolumn{1}{|c|}{ Source } & $\begin{array}{c}\text { Sum of Squares } \\
\text { Type III }\end{array}$ & df & $\begin{array}{c}\text { Quadratic } \\
\text { Mean }\end{array}$ & F & Sig. \\
\hline Corrected model & $933.678^{\mathrm{a}}$ & 4 & 233.419 & 79.106 & 0.000 \\
\hline Intersection & $97,595.939$ & 1 & $97,595.939$ & 33075.346 & 0.000 \\
\hline $\begin{array}{l}\text { Likely to keep job in six } \\
\text { months }\end{array}$ & 933.678 & 4 & 233.419 & 79.106 & 0.000 \\
\hline Error & $19,200.307$ & 6,507 & 2.951 & - & - \\
\hline Total & $377,756.000$ & 6,512 & - & - & - \\
\hline Corrected total & $20,133.985$ & 6,511 & - & - & - \\
\hline
\end{tabular}

Note: $\mathrm{a}-R^{2}=0.046$ ( $R$ corrected squared $\left.=0.046\right)$. Dependent variable: Level of current job satisfaction 2010 . Source: own elaboration from the Survey of Quality of Life at Work (Ministry of Employment and Social Security, 2010). 


\begin{tabular}{|c|c|c|c|c|c|c|}
\hline \multirow{2}{*}{ Parameter } & \multirow{2}{*}{ B } & \multirow{2}{*}{$\begin{array}{l}\text { Standard } \\
\text { Error }\end{array}$} & \multirow{2}{*}{$\mathbf{t}$} & \multirow{2}{*}{ Sig. } & \multicolumn{2}{|c|}{$\begin{array}{c}\text { Confidence Interva } \\
95 \%\end{array}$} \\
\hline & & & & & $\begin{array}{l}\text { Lower } \\
\text { Limit }\end{array}$ & $\begin{array}{l}\text { Upper } \\
\text { Limit }\end{array}$ \\
\hline Intersection & 7.056 & 0.109 & 64.692 & 0.000 & 6.843 & 7.270 \\
\hline Highly likely & 0.595 & 0.112 & 5.295 & 0.000 & 0.374 & 0.815 \\
\hline Quite likely & 0.157 & 0.118 & 1.327 & 0.184 & -0.075 & 0.388 \\
\hline Somewhat unlikely & -0.509 & 0.134 & -3.787 & 0.000 & -0.773 & -0.246 \\
\hline Very unlikely & -0.797 & 0.166 & -4.806 & 0.000 & -1.122 & -0.472 \\
\hline $\begin{array}{l}\text { Not applicable (contract } \\
\text { finalization, retirement, etc.) }\end{array}$ & $0^{\mathrm{a}}$ & - & - & - & - & - \\
\hline
\end{tabular}

Note: a - We assign the value zero to this parameter because it is redundant. Dependent variable: Current job satisfaction level (2010).

Source: Own elaboration from the Survey of Quality of Life at Work (Ministry of Employment and Social Security, 2010).

Next, we apply a statistical estimation method that incorporates the ordinal character of the dependent variable. This is the ordinal probit regression. The purpose is to analyse the influence of various explanatory variables on the level of job satisfaction with the current job.

In the ECVT, each worker rates job satisfaction on a scale of 0 to 10 , where 0 is "no satisfaction" and 10 is "high satisfaction".

From the responses, we define the ordinal variable that equals 1, 2, and 3 according to satisfaction level. Satisfaction can be low (responses 0-3), medium (responses 4-7), and high (answers 8 to 10). This new variable becomes the dependent variable in the subsequent empirical study. We redefine the variables as is common in studies of job satisfaction (e.g., Álvarez and Miles, 2006; Sánchez et al., 2007). Both studies apply ordered probit models, which report the factors that increase or decrease job satisfaction on a scale.

The redefinition of the variable is useful because although the ordered probit model could also be applied without transforming the variable, it is simpler to interpret the results if we only have 3 categories (high, medium, and low) than if we have a scale of 0 to 10 .

The novelty of this work appears in the different combinations of the explanatory variables in the model. In this case, the explanatory variables are sex, age, and educational level (personal variables), income, type of contract, and type of working day (variables inherent in work), and teamwork and training activities (variables regarding employability).

Regarding the variables that influence employability, we assume that a job that allows workers to develop their skills and abilities will help to improve their employability. Alvarez and Miles (2006) propose 3 options that could help to improve the human capital of workers and, consequently, their employability. These are: a) giving workers different tasks that require different knowledge, b) integrating them into autonomous working teams, and c) providing them with continuous training courses. 
Table 7 | Estimations of Parameters (ordinal probit regression)

\begin{tabular}{|c|c|c|c|c|c|c|}
\hline & \multirow{2}{*}{$\begin{array}{l}\text { Coeffi- } \\
\text { cient }\end{array}$} & \multirow{2}{*}{$\begin{array}{c}\text { Standard } \\
\text { error }\end{array}$} & \multirow{2}{*}{ Wald } & \multirow{2}{*}{ Sig. } & \multicolumn{2}{|c|}{$\begin{array}{c}\text { Confidence } \\
\text { Interval } 95 \%\end{array}$} \\
\hline & & & & & $\begin{array}{l}\text { Lower } \\
\text { Limit }\end{array}$ & $\begin{array}{l}\text { Lower } \\
\text { Limit }\end{array}$ \\
\hline Sex = man & -0.079 & 0.001 & $13,494.498$ & 0.000 & -0.081 & -0.078 \\
\hline Sex = woman & $0^{\mathrm{a}}$ & - & - & - & - & - \\
\hline Education level = illiterate & 8.025 & 0.000 & - & - & 8.025 & 8.025 \\
\hline Education level = less than primary studies & 0.032 & 0.003 & 158.992 & 0.000 & 0.027 & 0.037 \\
\hline Education level = primary studies & 0.100 & 0.001 & $5,343.904$ & 0.000 & 0.097 & 0.103 \\
\hline Education level = secondary studies & 0.077 & 0.001 & $4,325.567$ & 0.000 & 0.075 & 0.079 \\
\hline Education level = primary professional training & 0.214 & 0.001 & $26,436.775$ & 0.000 & 0.211 & 0.216 \\
\hline Education level = secondary professional training & 0.119 & 0.001 & $9,076.338$ & 0.000 & 0.116 & 0.121 \\
\hline Education level = pre-university studies & 0.032 & 0.001 & 692.369 & 0.000 & 0.030 & 0.035 \\
\hline Education level = degree university studies & 0.056 & 0.001 & $2,195.271$ & 0.000 & 0.054 & 0.059 \\
\hline Education level = master university studies & $0^{\mathrm{a}}$ & - & - & - & - & - \\
\hline Age $=$ from 16 to 25 years old & -0.246 & 0.008 & 943.500 & 0.000 & -0.262 & -0.230 \\
\hline Age $=$ from 26 to 35 years old & -0.268 & 0.008 & $1,135.921$ & 0.000 & -0.284 & -0.253 \\
\hline Age $=$ from 36 to 45 years old & -0.341 & 0.008 & $1,837.729$ & 0.000 & -0.356 & -0.325 \\
\hline Age $=$ from 46 to 55 years old & -0.357 & 0.008 & $2,017.422$ & 0.000 & -0.373 & -0.342 \\
\hline Age $=$ from 56 to 65 years old & -0.132 & 0.008 & 271.094 & 0.000 & -0.147 & -0.116 \\
\hline Age $=$ more than 65 years old & $0^{\mathrm{a}}$ & - & - & - & - & - \\
\hline Net incomes $=$ below 600 & -0.168 & 0.008 & 439.561 & 0.000 & -0.184 & -0.152 \\
\hline Net incomes $=$ from 600 to 1000 & -0.194 & 0.008 & 601.064 & 0.000 & -0.210 & -0.179 \\
\hline Net incomes $=$ from 1001 to 1200 & -0.127 & 0.008 & 258.898 & 0.000 & -0.143 & -0.112 \\
\hline Net incomes $=$ from 1201 to 1600 & 0.039 & 0.008 & 24.027 & 0.000 & 0.023 & 0.054 \\
\hline Net incomes = from 1601 to 2100 & 0.189 & 0.008 & 571.096 & 0.000 & 0.173 & 0.204 \\
\hline Net incomes = from 2101 to 3000 & 0.313 & 0.008 & $1,543.500$ & 0.000 & 0.297 & 0.328 \\
\hline Net incomes $=$ from 3001 to 4500 & 0.219 & 0.008 & 691.059 & 0.000 & 0.203 & 0.236 \\
\hline Net incomes $=$ from 4501 to 6000 & 0.414 & 0.009 & $2,078.689$ & 0.000 & 0.396 & 0.432 \\
\hline Net incomes $=$ more than 6000 & $0^{\mathrm{a}}$ & - & - & - & - & - \\
\hline Type of job contract = temporary & -0.152 & 0.001 & $39,235.261$ & 0.000 & -0.154 & -0.151 \\
\hline Type of job contract = permanent & $0^{\mathrm{a}}$ & - & - & - & - & - \\
\hline Working hours = full-time & -0.032 & 0.001 & 873.302 & 0.000 & -0.034 & -0.030 \\
\hline Working hours = part-time & $0^{\mathrm{a}}$ & - & - & - & - & - \\
\hline Teamwork = yes & 0.138 & 0.001 & $27,869.644$ & 0.000 & 0.136 & 0.140 \\
\hline Teamwork = no & $0^{\mathrm{a}}$ & - & - & - & - & - \\
\hline Do training activities = yes & 0.243 & 0.002 & $19,356.256$ & 0.000 & 0.239 & 0.246 \\
\hline Do training activities $=$ no & 0.051 & 0.002 & 889.456 & 0.000 & 0.048 & 0.055 \\
\hline Do training activities = not known & $0^{\mathrm{a}}$ & - & - & - & - & - \\
\hline
\end{tabular}

Note: Link function: Probit. Incomes are monthly and the monetary units are euros.

$\mathrm{a}-$ We assign the value zero to this parameter because it is redundant.

Source: own elaboration from the Survey of Quality of Life at Work (Ministry of Employment and Social Security, 2010). 
In our analysis, we have included 2 of the cited options (teamwork and carrying out training activities) because both are included in the ECVT although there could be more that improve the employability of workers. Also, according to the studies on the subject, there is a range of variables that influence employability; most authors agree that "training and/or apprenticeships" improve employability (we can quote the studies by Groot and Maassen Vann de Brink (2000) and Van Der Klink et al. (2014) for example), while the other variables are open to question.

The "teamwork" variable is located within the field of interpersonal relationships; talent can be better used if it is fostered in its dual nature: individual and part of a team. We believe that teamwork forms part of workers' training process. It is employer, depending on the type of task, who must strengthen individual and/or teamwork, and workers will have to manage both situations. Often there are processes in organisations that require the coordinated work of different departments; in these cases, if the working atmosphere is good, this leads to an improvement in productivity and job satisfaction.

Table 7 shows the parameters estimation. The number of parameters is the number of categories of each variable minus one. All parameters are significant. The Wald statistic is the square of the ratio between the parameter and its standard error. Table 8 shows the estimated probabilities for three response categories (low, medium, and high job satisfaction) for each case (temporary versus permanent work).

Table 8 | Estimated Probabilities (ordinal probit regression)

\begin{tabular}{|l|l|c|c|c|}
\hline \multicolumn{2}{|c|}{ Type of Contract } & $\begin{array}{c}\text { Estimated Probability } \\
\text { for the Response } \\
\text { Category: } \mathbf{1 . 0 0} \\
\text { (low level of job } \\
\text { satisfaction) }\end{array}$ & $\begin{array}{c}\text { Estimated Probability } \\
\text { for the Response } \\
\text { Category: } \mathbf{2 . 0 0} \\
\text { (medium level of job } \\
\text { satisfaction) }\end{array}$ & $\begin{array}{c}\text { Estimated Probability } \\
\text { for the Response } \\
\text { Category: } \mathbf{3 . 0 0} \\
\text { (high level of job } \\
\text { satisfaction) }\end{array}$ \\
\hline \multirow{2}{*}{ Temporary } & Number & $3,726,104$ & $3,726,104$ & $3,726,104$ \\
\cline { 2 - 5 } & Mean & 0.0493 & 0.4854 & 0.4653 \\
\hline \multirow{2}{*}{ Permanent } & Number & $11,253,049$ & $11,253,049$ & $11,253,049$ \\
\cline { 2 - 5 } & Mean & 0.0289 & 0.4057 & 0.5653 \\
\hline
\end{tabular}

Note: Link function: Probit

Source: own elaboration from the Survey of Quality of Life at Work (Ministry of Employment and Social Security, 2010).

\section{Results and Discussion}

The number of permanent workers fell by 5.03\% during 2007-2012, but the number of temporary workers fell by $36.6 \%$ in this period. However, the average levels of job satisfaction grew slightly during 2007-2010, possibly due to lower job requirements of employed workers.

Figure 1 shows that when the category "likely to keep job in six months" rates 0,1 , 2 , or 3 , then job satisfaction usually rates 8,9 , and 10 . This is a low job satisfaction rate. These results confirm Origo and Pagani's (2009) idea that improvement in job security generates an improvement in job satisfaction. Chadi and Hetschko (2013) present evidence that working on a temporary contract lowers current job satisfaction. They use ordinary 
least squares (OLS) estimation as well as probit models. Their results confirm the findings of Boswell et al. (2005) for a different sample.

Table 4 shows that the lowest level of job satisfaction occurs when the probability of keeping a job is low. Accordingly, the linear model shows negative coefficients in the categories "somewhat unlikely" and "very unlikely". This suggests that the level of job satisfaction decreases.

We apply an ordinal probit model and group job satisfaction into three categories (Table 7). We find that temporary workers are less satisfied with their jobs (by the negative sign of its coefficient). We also find that workers who work in teams and do training activities are more satisfied with their jobs. We thus consider teamwork and training activities as variables that measure worker employability.

Using the same methodology, Baruffini and Origo (2014) identify how job insecurity affects temporary workers. They also use ordered probit models. The results show that job stability and security are not associated, and that job satisfaction is relatively low, especially when job security is low. In the study by Buddelmeyer et al. (2015) the results of estimating ordered logit regression models show that male temporary workers have noticeably lower job satisfaction levels, although this association becomes weaker with permanent employment.

Table 8 shows the relationship between contract type and job satisfaction. We find that $4.93 \%$ of temporary workers rate their job satisfaction as low, $48.54 \%$ rate it as medium, and $46.53 \%$ rate it as high. If the worker is permanent, however, these results are $2.89 \%$, $40.57 \%$, and $56.53 \%$, respectively. The highest estimated probability for temporary workers $(48.54 \%)$ is associated with medium job satisfaction; the highest estimated probability for permanent workers $(56.53 \%)$ is associated with high job satisfaction. This suggests that temporary workers have less job satisfaction than permanent workers. The results of correspondence analysis, linear modelling and ordinal probit regression are coherent with each other.

\section{Conclusions}

People with temporary contracts are those who have failed to find a secure employment option, as it is the organisation that determines the length of the contract, in other words, it is companies that make workers redundant and not workers who leave the company. In times of economic crisis, the latter scenario is less likely to occur, due to the lack of jobs. Temporary work is usually an access channel to the job market for recently qualified young workers; and currently, when many adult workers have lost their jobs as a consequence of the different employment regulations, finding a job, even if it is temporary, is a way to survive.

This paper analyses job stability and satisfaction during the Spanish economic crisis. We find through a correspondence analysis that if workers feel that their job retention is unlikely, their job satisfaction is the lowest; on the contrary, if workers feel that they are likely to retain their jobs, their job satisfaction is the highest. Through a linear model, we also find a negative coefficient for level of job satisfaction if the probability of keeping the job is somewhat unlikely or very unlikely.

The ordinal probit regression provides the following conclusions. Temporary workers have less job satisfaction than permanent workers. Workers on teams and who do training activities are more satisfied with their jobs. We use teamwork and training activities as 
variables to measure worker employability. The length of employment contracts can be less important if workers feel that they are not in danger of losing their jobs. Our results show that worker employability favours job satisfaction. This research uses empirical static analysis in 2010 .

Our dynamic study also analyses salaried workers by contract type during 2006-2012. We find that temporary workers are the first ones to lose their jobs and are the most harmed by the Spanish economic crisis. Accordingly, temporary workers are more likely than permanent workers to be unemployed; the worst years were 2009 and 2012. The average level of job satisfaction increases slightly for salaried workers, both temporary and permanent, during 2007-2010. This trend is slightly higher in women. The high unemployment rate, which makes employed workers feel lucky to have jobs, explains most of these findings.

We conclude that although temporary workers are less satisfied with their jobs than permanent workers, as we demonstrate theoretically and empirically, the workeremployability variables (teamwork and training activities) increase job satisfaction. In other words, temporary workers have lower levels of job satisfaction than those who have permanent contracts, although from 2008 on, the average job satisfaction figures rise slightly for both types of workers. Future research might continue the study of the evolution of the labour market, its effects on job satisfaction, and the welfare of the country.

We also find that if companies value and want to recruit talent in normal economic conditions, the market is open to anyone who stays active, up-to-date, and goal-oriented. If workers add value to the firms that are willing to recognize and hire them, economies achieve job stability.

\section{References}

Agypt, B., Rubin, B. A. (2012). Time in the New Economy: The Impact of the Interaction of Individual and Structural Temporalities on Job Satisfaction. Journal of Management Studies, 49(2), 403-428. DOI: 10.1111/j.1467-6486.2011.01021.x.

Alba, A. (1998). How Temporary is Temporary Employment in Spain? Journal of Labour Research, 19(4), 695-710. DOI: 10.1007/s12122-998-1056-5.

Álvarez, G., Miles, D. (2006). El papel de la empleabilidad en la satisfacción laboral de los trabajadores temporales. Revista Galega de Economía, (The role of employability in job satisfaction of temporary workers. Galician Economic Journal), 15(2), 1-20.

Amuedo, C. (2000). Work Transitions Into and Out of Involuntary Temporary Employment in a Segmented Market: Evidence from Spain. Industrial and Labour Relations Review, 53(2), 309-325. DOI: 10.1177/001979390005300207.

Baruffini, M., Origo, F. (2014). Job Satisfaction and Flexicurity over the Business Cycle: Evidence from Swiss Individual-Level Data, in ERSA Conference Papers No. ersa14p366. European Regional Science Association.

Bernhard-Oettel, C., Sverke, M., De Witte, H. (2005). Comparing Three Alternative Types of Employment with Permanent Full-Time Work; How Do Employment Contract and Perceived Job Conditions Relate to Health Complaints? Work \& Stress, 19(4), 301-318. DOI: 10.1080/02678370500408723.

Boswell, W. R., Boudreau, J. W., Tichy, J. (2005). The Relationship between Employee Job Change and Job Satisfaction: the Honeymoon-Hangover Effect. Journal of Applied Psychology, 90(5), 882-892. DOI: 10.1037/0021-9010.90.5.882. 
Bowling, N. A, Beehr, T. A., Wagner, S. H., Libkuman. T. M. (2005). Adaptation-Level Theory, Opponent Process Theory, and Dispositions: An Integrated Approach to the Stability of Job Satisfaction. Journal of Applied Psychology, 90(6), 1044-1053.

DOI: 10.1037/0021-9010.90.6.1044.

Buddelmeyer, H., McVicar, D., Wooden, M. (2015). Non-Standard "Contingent" Employment and Job Satisfaction: A Panel Data Analysis. Industrial Relations: A Journal of Economy and Society, 54(2), 256-275. DOI: 10.1111/irel.12090.

Cesário, F. S., Gestoso, C. G., Peregrín, F. M. M. (2012). Contrato de trabalho, compromisso e satisfação: moderação pela empregabilidade. RAE-Revista de Administração de Empresas, (Contract work, commitment and satisfaction: moderation by employability. RAE- Journal of Business Administration), 52(3), 345-359.

Chadi, A., Hetschko, C. (2013). Flexibilisation without Hesitation? Temporary Contracts and Workers' Satisfaction. IAAEU Discussion Paper Series in Economics No. 04/2013.

De Cuyper, N., Van Der Heijden, B. I., De Witte, H. (2011). Associations between Perceived Employability, Employee Well-Being, and Its Contribution to Organizational Success: a Matter of Psychological Contracts? The International Journal of Human Resource Management, 22(7), 1486-1503. DOI: 10.1080/09585192.2011.561962.

De Witte, H., Naswall, K. (2003). “Objective” vs "Subjective” Job Insecurity: Consequences of Temporary Work for Job Satisfaction and Organizational Commitment in Four European Countries. Economic and Industrial Democracy, 24(2), 149-188.

DOI: $10.1177 / 0143831 \times 03024002002$.

Dimian, G. C., Ileanu, B., Jablonský, J., Fábry, J. (2013). Analysis of European Labour Market in the Crisis Context. Prague Economic Papers, 22(1), 50-71. DOI: 10.18267/j.pep.440.

Dormann, C., Zapf, D. (2001). Job Satisfaction: A Meta-Analysis of Stabilities. Journal of Organizational Behavior, 22(5), 483-504. DOI: 10.1002/job.98.

Elfering, A., Semmer, N. K., Kalin, W. (2000). Stability and Change in Job Satisfaction at the Transition from Vocational Training into "Real Work". Swiss Journal of Psychology, 59(4), 256-271. DOI: 10.1024//1421-0185.59.4.256.

Fernández, J. (2013). Generación de empleos de calidad y su importancia para el desarrollo. RIMISP. Centro Latinoamericano para el Desarrollo Rural. (Creation of quality jobs and its importance for development. RIMISP. Latin American Center for Rural Development).

Finn, D. (2000). From Full Employment to Employability: A New Deal for Britain's Unemployed. International Journal of Manpower, 21(5), 384-395. DOI: 10.1108/01437720010377693.

Fundación FOESSA (2014). Fomento de Estudios Sociales y de Sociología Aplicada. VII Informe sobre exclusión y desarrollo social en España. (Promotion of Social Studies and Applied Sociology. VII Report about exclusion and social development in Spain),

Galtier, B., Gautié, J. (2001). Employment Protection and Labour Market Policies: Trade-Offs and Complementarities? The Case of France. International Labour Organization, Paris.

Gamero, C. (2005). Análisis microeconómico de la satisfacción laboral. Consejo Económico y Social, (Microeconomic analysis of job satisfaction. Economic and Social Council), Madrid.

Groot, W., Maassen Vann De Brink, H. (2000). Education, Training and Employability. Applied Economics, 32(5), 573-581. DOI: 10.1080/000368400322471.

Guest, D., Conway, N. (1997). Employee Motivation and the Psychological Contract. Chartered Institute of Personnel and Development, London.

INE Instituto Nacional de Estadística (2013). Spanish National Statistics Institute, EAPS, Economically Active Population Survey (methodology 2005), Madrid. 
International Labour Organization (2011). España. Empleos de calidad para una nueva economía. Instituto Internacional de Estudios Laborales, (Spain. Quality Jobs for a New Economy. International Institute of Labour Studies), Ginebra.

IVIE Instituto Valenciano de Investigaciones Económicas (2006). El contexto socio-laboral de los jóvenes, 1996-2005. Cuadernos de Capital Humano, (IVIE Valencian Institute of Economic Research (2006). The Socio-Labour Context of Youth 1996-2005. Human Capital Notebooks), 68.

IVIE (2009a). Capital humano: una inversión rentable. Cuadernos de Capital Humano, (Human Capital: a Profitable Investment. Human Capital Notebooks), 100.

IVIE (2009b). Flexibilidad Laboral y características de los jóvenes. Cuadernos de Capital Humano, (Labour Flexibility and Characteristics of Youth. Human Capital Notebooks), 106.

IVIE (2012a). Crisis y mercado de trabajo: una perspectiva regional. Cuadernos de Capital Humano, (Crisis and Labour Market: a Regional Perspective. Human Capital Notebooks), 133.

IVIE (2012b). Los jóvenes y el empleo en tiempos difíciles. Cuadernos de Capital Humano, (Youth and Employment in Troubled Times. Human Capital Notebooks), 137.

Jacoby, S. M. (1999). Are Career Jobs Headed for Extinction? California Management Review, 42(1), 123-145. DOI: 10.2307/41166022.

Laparra, M., Eransus, B. P., Lasheras, R., Carbonero, M. A., Guinea-Martín, D., Zugasti, N., Ayala, L., Martínez, L., Sarasa, S., García, A., Guillén, A., Pavolini, E., Luque, D., Anaut, S. (2012). Crisis y fractura social en Europa. Causas y efectos en España. Obra Social "La Caixa", (Crisis and social divide in Europe. Causes and effects in Spain. "La Caixa" Social Assistance), Barcelona.

Medina, E., Herrarte, A., Vicéns, J. (2010). Inmigración y desempleo en España: impacto de la crisis económica. Información Comercial Española, ICE. Revista de economía, (Immigration and unemployment in Spain: Impact of Economic Crisis. Spanish Commercial Information, ICE. Economic Journal), 854, 37-48.

Merino, M. C., Somarriba, N., Negro, A. M. (2012). Un análisis dinámico de la calidad del trabajo en España. Los efectos de la crisis económica. Estudios de Economía Aplicada, (A Dynamic Analysis of Quality at Work in Spain. The Effects of Economic Crisis. Studies of Applied Economics), 30(1), 261-282.

Muñoz, R. (2015). Reflexión acerca de la temporalidad en la contratación en nuestra legislación. Lecture at the Asociación de Jóvenes Letrados. (Reflection about Temporary and Work Contracts in our Legislation. Lecture at the Association of Young Lawyers), Available at: http://jovenesletrados.es/articulos/laboral-contratacion-temporal.html

Origo, F., Pagani, L. (2009). Flexicurity and Job Satisfaction in Europe: The Importance of Perceived and Actual Job Stability for Well-Being at Work. Labour Economics, 16(5), 547-555. DOI: 10.1016/j.labeco.2009.02.003.

Pedraza, E., Amaya, G., Conde, M. (2010). Desempeño laboral y estabilidad del personal administrativo contratado de la Facultad de Medicina de la Universidad del Zulia. Revista de Ciencias Sociales (RCS), (Job Performance and Stability of Administrative staff in Faculty of Medicine at University of Zulia. Journal of Social Sciences (RCS)), 16(3), 493-505.

Sánchez, S. M., Fuentes, F. J., Artacho, C. (2007). La perspectiva de género en el análisis de la satisfacción laboral: una aplicación empírica mediante modelos logit y probit. Cuadernos de Gestión, (The Gender Perspective in the Analysis of Job Satisfaction: Empirical Application with Logit and Probit Models. Management Notebooks), 7(2), 55-67.

Sánchez-Sellero, M. C., Sánchez-Sellero, P., Cruz-González, M. M., Sánchez-Sellero, F. J. (2013). Sobrecualificación en tiempos de crisis. Revista Venezolana de Gerencia (RVG), (Overqualification in Times of Crisis. Venezuelan Management Journal (RVG)), 18(64), 584-610. 
Sánchez-Sellero, M. C., Sánchez-Sellero, P., Cruz-González, M. M., Sánchez-Sellero, F. J. (2014). Características organizacionales de la satisfacción laboral en España. RAE-Revista de Administração de Empresas, (Organizational Characteristics in the Labour Satisfaction in Spain. RAE- Journal of Business Administration), 54(5), 537-547.

DOI: 10.1590/s0034-759020140507.

Scholarios, D., Van Der Heijden, B. I., Van Der Schoot, E., Bozionelos, N., Epitropaki, O., Jedrzejowicz, P., Van der Heijde, C. M. (2008). Employability and the Psychological Contract in European ICT Sector SMEs. The International Journal of Human Resource Management, 19(6), 1035-1055. DOI: 10.1080/09585190802051337.

Socorro, F. (2004). Estabilidad laboral: Otro paradigma que cambia. (Stability at work: Another Paradigm that Changes), [Retrieved 2015-1-22] Available at: http://www.degerencia.com/ articulo/estabilidad_laboral_otro_paradigma_que_cambia

Stone, K. (2001). The New Psychological Contract: Implications of the Changing Work-Place for Labor and Employment Law. UCLA Law Review, 48(3), 519-661.

Ministry of Employment and Social Security (2010). Survey of Quality of Life at Work. Madrid.

Toharia, L. (2005). El problema de la temporalidad en España: un diagnóstico. Ministerio de Trabajo y Asuntos Sociales, (The Problem of Temporality in Spain: a Diagnosis. Ministry of Labour and Social Affairs), Madrid.

Truch, E. (2001). Managing Personal Knowledge; the Key to Tomorrow's Employability. Journal of Change Management, 2(2), 102-105. DOI: 10.1080/714042494.

Van Der Klink, M., Van Der Heijden, B. I. J. M., Boon, J., Van Rooij, S. W. (2014). Exploring the Contribution of Formal and Informal Learning to Academic Staff Member Employability: A Dutch Perspective. Career Development International, 19(3), 337-356. DOI: 10.1108/cdi-03-2013-0030.

Wilkin, C. L. (2013). I Can't Get No Job Satisfaction: Meta-Analysis Comparing Permanent and Contingent Workers. Journal of Organizational Behavior, 34(1), 47-64.

DOI: 10.1002/job.1790. 